\title{
EFFECTS OF DIFFERENT TILLAGE PRACTICES AND CROPPING PATTERNS ON SOIL PHYSICAL PROPERTIES AND CROP PRODUCTIVITY
}

\author{
${ }^{1}$ M. K. ALAM, N. ${ }^{1}$ SALAHIN, ${ }^{2}$ M. H. RASHID AND ${ }^{3}$ M. A. SALAM \\ ${ }^{1}$ Scientific Officer, Soil Science Division, Bangladesh Agricultural Research Institute, Gazipur, \\ Bangladesh \\ ${ }^{2}$ Senior Scientific Officer, Soil Science Division, Bangladesh Agricultural Research Institute, Gazipur, \\ Bangladesh \\ ${ }^{3}$ Faculty of Earth Science, Universiti Malaysia Kelantan, Jeli Campus, Kelantan, Malaysia
}

Corresponding author:abdus@umk.edu.my

\begin{abstract}
A series of experiments using nine treatment combinations comprising three tillage practices (zero tillage, conventional tillage and deep tillage) and three cropping patterns (wheatfallow-T. aman, wheat-mungbean-T. aman and wheat-dhaincha-T. aman) were examined in a split- plot design at Bangladesh Agricultural Research Institute (BARI), Gazipur, Bangladesh during 2008-2009 and 2009-2010 to study the effect of different tillage practices and cropping patterns on soil physical properties and crop productivity in a previously puddled soil. Soil physical properties viz. bulk density, particle density and porosity showed insignificant result due to tillage practices and cropping patterns but soil moisture retentive properties demonstrated significant outcomes. Deep tillage with dhaincha (Sesbania rostrata) and mungbean (Vigna radiata L. Wilczek) biomass incorporation conserved moisture in the soil profile and improved other soil physical properties i.e. reduced the bulk density, increased porosity and available water content of soil. The highest grain yield of wheat and rice was recorded in the deep tillage with wheat-dhaincha-T. aman cropping pattern and lowest in zero tillage with fallow based cropping pattern.
\end{abstract}

KEYWORDS: Tillage practices, cropping patterns, soil physical properties, crop productivity, plough pan.

\section{Introduction}

Agriculture is the main stay of economy of Bangladesh. Rice (Oryza sativa L.) with wheat (Triticum aestivum L.) as second in ranking is the major cereal in Bangladesh. There are different kinds of tillage operations such as no tillage, reduced tillage, deep tillage etc. (Simmons and Nafziger, 2012). Recently, the reduced tillage technique has been gaining popularity (Jenane et al., 2012). For sowing seed of wheat or planting of rice, different types of agricultural tools are used in farming for initial land preparation which among the crop production factors contributes up to $20 \%$ (Khurshid et al., 2006). During such cultivation, sub-soil compaction is usually caused by tillage system specifically through mechanical practices. Repeated ploughing may result in plough pan formation in cultivated soil due to use of heavy weight tillage machineries. Plough pans are formed in the same profile under power tiller and country plough treatment 
mostly in rice field (Islam et al., 2005). It is found in clayey soils which are cultivated in a wet condition and are puddled for transplanted rice cultivation. Puddling is advantageous for rice cultivation but imposes limitations for upland crops. The extent of plough pan formation is about 2.30 million hectares in Tista, Ganges, Brahmaputra, Meghna flood plains, Madhupur Tracts and Barind areas (Brammer, 2000). The presence of plough pan may influence the physical properties of soil such as soil texture, structure, density, pore space, soil consistency, soil temperature and may also affect soil chemical properties such as soil $\mathrm{pH}$, soil organic matter and availability of soil nutrients. The most direct effect of soil compaction is an increase in the bulk density of soil and destruction of soil structure. Under the conventional tillage system a plough pan layer is developed that may impose changes in soil physical properties and may lead to a decrease in soil physical quality (Bertolino et al., 2010). Intensive tillage is favourable for the formation of plough pan that decreases soil bulk density and could develop penetration resistance up to tilled depth (Singh et al., 1998). Khan (1996) observed that compacted layers located at a shallower practice than the normal rooting practice, may be an obstruction for roots as a consequence of low porosity and too high mechanical impedance.

The major cereal cropping system of South Asia is rice and wheat grown on the same field but in different seasons during one year. After rice, wheat has become an important component of cropping pattern in Bangladesh. It is cultivated mostly after cultivation of Aman rice (Mazid et al., 1990). Cropping pattern has immense effect on soil physical and chemical properties and thereby on crop productivity (Ranamukhaarachchi et al., 2005). Soil fertility often changes in response to land use, cropping patterns and land management practices (Rahman and Ranamukhaarachchi, 2003). Intensive cropping promotes high levels of nutrient extraction from soils without natural replenishment. Use of green manure especially legumes in a cropping pattern could help restore crop productivity. Moreover, inclusion of legumes in crop rotations protects the fragile soil surface by restoring the organic matter content and organic fertility of these soils. This would also help to restore the natural fertility of these soils (Ahmad et al., 2010). Productions of component crops in the cropping patterns (especially, rice and wheat) in Bangladesh are low in comparison with many other countries. Inappropriate tillage practices and cropping system management are some of the reasons behind the low yield of the crops. Therefore, the study was conducted to identify the appropriate tillage practices and suitable cropping pattern towards increasing productivity of wheat and rice in an alternative unpuddled and puddled soil.

\section{Materials and Methods}

A series of experiments were conducted at the Bangladesh Agricultural Research Institute (BARI), Joydebpur, Gazipur during 2008-2009 and 2009-2010. The study area was under the agro-ecological zone, Modhupur Tract and the soil belongs to the Chhiata series of the Grey Terrace Soils (Aeric Albaquept) under the order Inceptisols (SRDI, 2005). The textural class is clay loam with soil $\mathrm{pH}$ ranging from 5.5-5.7 and the land type is medium high. The climate of the experimental area is sub-tropical, wet and humid. Heavy rainfall occurs in the monsoon and scanty at other times. There were nine treatment combinations comprising three tillage practices ( $T_{1}$ : zero tillage, $T_{2}$ : conventional tillage and $T_{3}$ : deep tillage) and three cropping patterns $\left(C_{1}\right.$ : wheat-fallow-T.aman, $\mathrm{C}_{2}$ : wheat-mungbean-T.aman and $\mathrm{C}_{3}$ : wheat-dhaincha-T.aman) examined in a split-plot design with three replications. Tillage depths were maintained as $0-4 \mathrm{~cm}$ depth for zero tillage, as $12-16 \mathrm{~cm}$ depth for conventional tillage and as $20-25 \mathrm{~cm}$ depth for deep tillage. 
In zero tillage seeds were placed just by making furrow with a hand rake. The conventional tillage was maintained by a power tiller, whereas the deep tillage was maintained by a chisel plough. The seeds of the first crop, wheat of all patterns were sown in the last week of November under unpuddled condition, mungbean and dhaincha were sown in the fourth week of March and thirty-day old seedlings of T. aman rice (BRRIdhan32) were transplanted in the second week of July under puddled condition for both years. Spacing for rice was maintained $25 \mathrm{~cm}$ apart between rows and $15 \mathrm{~cm}$ hill to hill with 3 seedlings per hill. Necessary gap filling was done 8 days after transplanting. Targeting a high yield goal of the crops in the cropping patterns, the rates of chemical fertilizer for each component crop were calculated based on soil test results using the BARC model (BARC, 2005). Weeding was done as planned and when necessary but no insecticides and pesticides were used, since the crop was free from insects and pathogen attack.

The wheat was harvested in the first week of April in both the years (2009 and 2010), mungbean pod picking was started in the first week of June and continued up to the third week of June, whereas rice was harvested in the second week of October for both years at full maturity. After pod picking, remaining biomass of mungbean was incorporated in the soil as brown manure. The total biomass of dhaincha was incorporated in the soil in the fourth week of June. For data collection of wheat and rice, five hills from each plot were sampled randomly. Both the crop (wheat and rice) was cut at the ground level. Threshing, cleaning, and drying of grains were done separately plotwise. The weights of grain and straw were recorded.

Table 1: Initial soil properties of experimental plots in 2008-2009

\begin{tabular}{c|c}
\hline Particle size distribution & Value \\
\hline Sand (\%) & 35.30 \\
\hline Silt (\%) & 37.29 \\
\hline Clay (\%) & 27.41 \\
\hline Textural class & Clay loam \\
\hline Bulk density $\left(\mathrm{g} \mathrm{cm}^{-3}\right)$ & 1.52 \\
\hline Particle density $\left(\mathrm{g} \mathrm{cm}^{-3}\right)$ & 2.58 \\
\hline Porosity (\%) & 37.98 \\
\hline Field capacity (\%) & 24.00 \\
\hline Permanent wilting point (\%) & 10.50 \\
\hline Available water content (cm) up to $15 \mathrm{~cm}$ & 3.05 \\
soil depth &
\end{tabular}

Soil samples were collected from the experimental field at $0-15 \mathrm{~cm}$ at the initial stage and after the completion of experiment and were then analyzed in the laboratory following standard procedures. Particle size and textural class analysis of the collected soils was done by hydrometer method (Black, 1965), bulk density and particle density of the soil samples were determined by core sampler method and pycnometer method, respectively (Karim et al., 1988). The soil porosity was computed from the relationship between bulk density and particle density using the Equation 1. Soil field capacity and permanent wilting point were determined using pressure plate apparatus, where available water was calculated using the Equation 2 (Black, 1965). 


$$
\begin{aligned}
& \text { Porosity }(\%)=(1-\mathrm{BD} / \mathrm{PD}) \mathrm{x} 100 \ldots \ldots \ldots \ldots \ldots \ldots \ldots \ldots \ldots \ldots \ldots \ldots \ldots \ldots \ldots \ldots \ldots \ldots \ldots \ldots \ldots \\
& \mathrm{d}=(\mathrm{FC}-\mathrm{PWP}) / 100 \times \mathrm{BD}
\end{aligned}
$$

The collected data on yields were statistically analyzed by F-test to examine the treatment effects and the mean differences were adjudged by Least Significant Difference Test (Gomez and Gomez, 1984) and ranking was indicated by letters. Correlation and regression between grain yields with yield components was performed. The software package MSTAT was followed for statistical analysis. The initial results of some important soil properties are shown in Table 1.

\section{Results and discussion}

Grain and biomass yield of mungbean and biomass yield of dhaincha as affected by tillage practices

The effect of tillage practices on grain yield of mungbean was found significant. The highest grain yield of mungbean was observed in deep tillage, whereas the lowest yields were obtained in the zero tillage (Table 2). As for biomass, the yield of mungbean and dhaincha were markedly different among tillage practices. Highest biomass of both green manuring crops grown in between two cereal crops was found in deep tillage treatment and lowest biomass was obtained in zero tillage treatment. The highest biomass yield of dhaincha $\left(18.44 \mathrm{t} \mathrm{ha}^{-1}\right)$ was recorded in deep tillage treatment which was similar to conventional tillage, whereas the lowest biomass $\left(14.83 \mathrm{tha}^{-1}\right)$ was recorded in the zero tillage treatment (Table 2).

Table 2: Grain and biomass yields of mungbean and dhaincha under different cropping tillage practices

\begin{tabular}{c|c|c|c}
\hline \multirow{2}{*}{ Treatments } & \multicolumn{2}{|c|}{ Mungbean yield $\left(\mathrm{t} \mathrm{ha}^{-1}\right)$} & Dhaincha yield $\left(\mathrm{t} \mathrm{ha}^{-1}\right)$ \\
\cline { 2 - 4 } & Grain & Biomass & Biomass \\
\hline $\mathrm{T}_{1}$ & $0.46 \mathrm{~b}$ & $9.21 \mathrm{~b}$ & $14.83 \mathrm{~b}$ \\
\hline $\mathrm{T}_{2}$ & $0.60 \mathrm{a}$ & $10.86 \mathrm{~b}$ & $16.86 \mathrm{a}$ \\
\hline $\mathrm{T}_{3}$ & $0.68 \mathrm{a}$ & $13.87 \mathrm{a}$ & $18.44 \mathrm{a}$ \\
\hline$C V(\%)$ & 10.16 & 5.10 & 4.02 \\
\hline$S E( \pm)$ & 0.04 & 0.33 & 0.43 \\
\hline
\end{tabular}

$\mathrm{P}>0.05$

Different letters indicated significant difference within columns.

\section{Effect of tillage practices and cropping patterns on soil bulk density, particle density and porosity}

The difference in bulk density among different tillage practices and cropping patterns alone and the interaction were insignificant (Table 3). The bulk density of $1.43 \mathrm{~g} \mathrm{~cm}^{-3}$ was recorded in deep tillage under wheat-dhaincha-T. aman cropping pattern, whereas it was $1.48 \mathrm{~g} \mathrm{~cm}^{-3}$ in zero tillage under wheat-fallow-T.aman cropping pattern. The higher amount of added biomass from dhaincha coupled with deep ploughing made the soil loose, more porous and less compacted and therefore the bulk density was found low under zero tillage with wheat-fallow-T. aman cropping pattern. The results of this study are consistent with that of Katsvairo et al., (2002), Oquist et al. (2006), Jabro et al. (2008), Husnjak et al. (2002) and Rahman et al. (2007) where it was shown that there were no differences in soil bulk density among different tillage treatments. Similar to 
bulk density, the effects of tillage practices, cropping patterns and their interactions on soil particle density were also not significant ranging from 2.54 to $2.57 \mathrm{~g} \mathrm{~cm}^{-3}$ in the surface layer $(0$ $15 \mathrm{~cm})$. This shows that the particle density was not altered easily by normal physical manipulation of soil. The finding was in full agreement with those findings of McFarland et al. (1991) where they showed that three years of disc tillage and no tillage did not alter the soil particle density.

Table 3: Effects of tillage practices, cropping patterns and their interactions on bulk density, particle density and porosity of post experimental soil

\begin{tabular}{|c|c|c|c|}
\hline \multirow{2}{*}{ Treatments } & \multicolumn{3}{|c|}{ Soil parameters } \\
\hline & Bulk density $\left(\mathrm{g} \mathrm{cm}^{-3}\right)$ & Particle density $\left(\mathrm{g} \mathrm{cm}^{-3}\right)$ & Porosity $(\%)$ \\
\hline \multicolumn{4}{|l|}{ Tillage treatments } \\
\hline $\mathrm{T}_{1}$ & 1.47 & 2.57 & 42.50 \\
\hline $\mathrm{T}_{2}$ & 1.45 & 2.55 & 43.11 \\
\hline $\mathrm{T}_{3}$ & 1.44 & 2.54 & 43.56 \\
\hline$C V(\%)$ & 4.69 & 5.35 & 6.02 \\
\hline$S E( \pm)$ & 0.01 & 0.003 & 0.36 \\
\hline \multicolumn{4}{|c|}{ Cropping pattern treatments } \\
\hline $\mathrm{C}_{1}$ & 1.46 & 2.56 & 42.82 \\
\hline $\mathrm{C}_{2}$ & 1.45 & 2.55 & 43.10 \\
\hline $\mathrm{C}_{3}$ & 1.45 & 2.55 & 43.26 \\
\hline$C V(\%)$ & 4.69 & 5.35 & 6.02 \\
\hline$S E( \pm)$ & 0.003 & 0.003 & 0.101 \\
\hline \multicolumn{4}{|c|}{ Interaction treatments } \\
\hline $\mathrm{T}_{1} \mathrm{C}_{1}$ & 1.48 & 2.57 & 42.41 \\
\hline $\mathrm{T}_{1} \mathrm{C}_{2}$ & 1.47 & 2.57 & 42.80 \\
\hline $\mathrm{T}_{1} \mathrm{C}_{3}$ & 1.47 & 2.57 & 42.80 \\
\hline $\mathrm{T}_{2} \mathrm{C}_{1}$ & 1.47 & 2.55 & 42.35 \\
\hline $\mathrm{T}_{2} \mathrm{C}_{2}$ & 1.45 & 2.55 & 43.14 \\
\hline $\mathrm{T}_{2} \mathrm{C}_{3}$ & 1.44 & 2.55 & 43.53 \\
\hline $\mathrm{T}_{3} \mathrm{C}_{1}$ & 1.45 & 2.55 & 43.14 \\
\hline $\mathrm{T}_{3} \mathrm{C}_{2}$ & 1.44 & 2.54 & 43.31 \\
\hline $\mathrm{T}_{3} \mathrm{C}_{3}$ & 1.43 & 2.54 & 43.70 \\
\hline$C V(\%)$ & 4.69 & 5.35 & 6.02 \\
\hline$S E( \pm)$ & 0.0056 & 0.006 & 0.17 \\
\hline
\end{tabular}

$\mathrm{P}>0.05$

Different letters indicated significant difference within columns

Likewise the effects of different tillage practices and cropping patterns alone and their interactions on soil porosity were also not significant as the values ranged from 42.41 to $43.70 \%$. The lowest soil porosity of $42.41 \%$ was recorded under zero tillage with wheat-fallow-T. aman cropping pattern and slightly higher porosity of $43.70 \%$ was observed under deep tillage with wheat-dhaincha-T. aman cropping pattern. Cogle et al. (1997) has reported that deep tillage increases soil porosity. As porosity is calculated from the relationship between soil bulk density and soil particle density, it is therefore very much influenced by bulk density as particle density is least altered by the agricultural crop management practices. 
Effects of tillage practices and cropping patterns on soil field capacity, permanent wilting point and available water content

The effect of different tillage practices, cropping patterns and their interactions on soil field capacity (FC) was found significant (Table 4). The lowest FC of $20.2 \%$ was recorded in the zero tillage under wheat-fallow-T. aman cropping pattern and the highest was $34 \%$ in deep tillage under wheat-dhaincha-T. aman cropping pattern. The bulk density of initial soil was $1.52 \mathrm{~g} \mathrm{~cm}^{-3}$, which decreased to $1.43 \mathrm{~g} \mathrm{~cm}^{-3}$ in the surface layer under wheat-dhaincha-T. aman cropping pattern. This shows that addition of sufficient amount of biomass in conjunction with tillage made surface soil loose and porous, which then enhanced the capacity of soil to store and retain more moisture resulting in increased field capacity.

Table 4: Effects of different tillage practices and cropping patterns on moisture retentive properties of post experimental soil

\begin{tabular}{|c|c|c|c|}
\hline \multirow[b]{2}{*}{ Treatments } & \multicolumn{3}{|c|}{ Soil parameters } \\
\hline & Field capacity (\%) & $\begin{array}{l}\text { Permanent wilting point } \\
(\%)\end{array}$ & $\begin{array}{l}\text { Available water content } \\
(\mathrm{cm})\end{array}$ \\
\hline \multicolumn{4}{|l|}{ Tillage treatments } \\
\hline $\mathrm{T}_{1}$ & $24.96 \mathrm{~b}$ & $10.17 b$ & $3.27 \mathrm{~b}$ \\
\hline $\mathrm{T}_{2}$ & $30.96 a$ & $13.50 \mathrm{a}$ & $3.81 \mathrm{a}$ \\
\hline $\mathrm{T}_{3}$ & $33.43 \mathrm{a}$ & $15.00 \mathrm{a}$ & $3.98 \mathrm{a}$ \\
\hline$C V(\%)$ & 4.57 & 6.62 & 9.58 \\
\hline$S E( \pm)$ & 0.70 & 1.236 & 0.33 \\
\hline \multicolumn{4}{|c|}{ Cropping pattern treatments } \\
\hline $\mathrm{C}_{1}$ & $28.54 b$ & $12.50 \mathrm{~b}$ & 3.53 \\
\hline $\mathrm{C}_{2}$ & $30.11 \mathrm{a}$ & $12.83 \mathrm{~b}$ & 3.77 \\
\hline $\mathrm{C}_{3}$ & $30.70 \mathrm{a}$ & $13.33 \mathrm{a}$ & 3.77 \\
\hline $\mathrm{CV}(\%)$ & 4.57 & 6.62 & 9.58 \\
\hline $\mathrm{SE}( \pm)$ & 0.45 & 0.16 & 0.12 \\
\hline \multicolumn{4}{|c|}{ Interaction treatments } \\
\hline $\mathrm{T}_{1} \mathrm{C}_{1}$ & $20.20 \mathrm{~d}$ & $10.00 \mathrm{f}$ & $2.26 \mathrm{c}$ \\
\hline $\mathrm{T}_{1} \mathrm{C}_{2}$ & $23.60 \mathrm{c}$ & $10.00 \mathrm{f}$ & $3.00 \mathrm{c}$ \\
\hline $\mathrm{T}_{1} \mathrm{C}_{3}$ & $23.60 \mathrm{c}$ & $10.50 \mathrm{f}$ & $2.89 \mathrm{c}$ \\
\hline $\mathrm{T}_{2} \mathrm{C}_{1}$ & $27.50 \mathrm{~b}$ & $13.00 \mathrm{e}$ & $3.20 \mathrm{ab}$ \\
\hline $\mathrm{T}_{2} \mathrm{C}_{2}$ & $29.00 \mathrm{~b}$ & $13.50 \mathrm{de}$ & $3.37 \mathrm{abc}$ \\
\hline $\mathrm{T}_{2} \mathrm{C}_{3}$ & $29.25 b$ & $14.00 \mathrm{~cd}$ & $3.29 \mathrm{abc}$ \\
\hline $\mathrm{T}_{3} \mathrm{C}_{1}$ & $32.50 \mathrm{ab}$ & $14.50 \mathrm{bc}$ & $3.92 \mathrm{bc}$ \\
\hline $\mathrm{T}_{3} \mathrm{C}_{2}$ & $33.75 \mathrm{a}$ & $15.00 \mathrm{ab}$ & $4.05 \mathrm{a}$ \\
\hline $\mathrm{T}_{3} \mathrm{C}_{3}$ & $34.00 \mathrm{a}$ & $15.50 \mathrm{a}$ & $3.97 \mathrm{a}$ \\
\hline$C V(\%)$ & 4.57 & 6.62 & 9.58 \\
\hline$S E( \pm)$ & 0.78 & 0.27 & 0.19 \\
\hline
\end{tabular}

\section{$\mathrm{P}>0.05$}

Different letters indicated significant difference within columns

The permanent wilting point (PWP) varied significantly with the adoption of different tillage practices, cropping patterns and their interactions (Table 4). The PWP ranged from 10\% under 
zero tillage with wheat-fallow-T. aman to $15.5 \%$ under deep tillage with wheat-dhaincha-T. aman cropping pattern. The water holding capacity of soil under wheat-dhaincha-T.aman cropping pattern was higher than that of wheat-fallow-T. aman cropping pattern because of addition of more organic matter in soils through green manuring using dhaincha. This contributed to the higher PWP of soils under wheat-dhaincha-T. aman cropping pattern. However, tillage practices showed significant effect on available soil moisture but available soil moisture was not significant by cropping patterns and their interactions (Table 4). This indicated that deep tillage particularly in the rabi season (middle October to middle March) may help increase the available water content. Manipulation of soil moisture dynamics with tillage could be one of the more feasible ways of increasing crop yields as explained by Rahman and Islam (1988).

\section{Effect of tillage practices on yield of wheat and rice}

The effects of tillage practice on the wheat and rice grain yield were significant and varied among three tillage practices (Tables $5 \& 6$ ). The highest yields of both the crops were in deep tillage and the lowest yields were obtained in the zero tillage treatment. Deep tillage favoured better root growth and nutrient uptake by the crop and hence positive physiological and metabolic activities and reproductive development of crop were probably influenced by increased tillage practices. Tillage practice influences favourably the soil-water-plant ecosystem, thereby affecting crop yields and quality. Ardell et al. (2000), Ranjan et al. (2006), Jabro et al. (2010) stated that deep tillage had significant effect on crop yields as wheat at grain filling stage did not suffer from soil moisture deficit. In general, with the rice crop the majority of roots penetrate into a depth of about 20-25 cm (Sharma et al., 1994). Therefore, the presence of a shallow plough pan which was developed by conventional tillage may restrict root growth and which may result in poor above ground plant growth as the nutrient uptake by the plant is reduced. The ultimate result is the reduction of grain yield of rice under zero and conventional tillage and in contrast, deep tillage significantly increased grain yield of rice over shallow land preparation consistently for two seasons (Wickramasinghe, 2011). Similarly deep tillage increased straw yield as a result of the increase in the aboveground biomass, a trend which was also shown in the previous year of experimentation.

Table 5: Effect of tillage depths on the yield and yield components of wheat in 2009-2010

\begin{tabular}{c|c|c|c|c|c|c|c}
\hline Tillage & $\begin{array}{c}\text { Spike } \\
\text { length } \\
(\mathrm{cm})\end{array}$ & $\begin{array}{c}\text { Grain } \\
\text { spike }\end{array}$ & $\begin{array}{c}1000 \text { grain } \\
\text { wt. }(\mathrm{g})\end{array}$ & $\begin{array}{c}\text { Grain } \\
\text { yield } \\
\left(\mathrm{t} \mathrm{ha}^{-1}\right)\end{array}$ & $\begin{array}{c}\text { Straw yield } \\
\left(\mathrm{t} \mathrm{ha}^{-1}\right)\end{array}$ & $\begin{array}{c}\text { Grain yield } \\
\left(\mathrm{t} \mathrm{ha}^{-1}\right) \\
2008-09\end{array}$ & $\begin{array}{c}\text { Straw yield } \\
\left(\mathrm{t} \mathrm{ha}^{-1}\right) \\
2008-09\end{array}$ \\
\hline $\mathrm{T}_{1}$ & 7.85 & $23.75 \mathrm{~b}$ & 37.25 & $2.21 \mathrm{c}$ & $3.52 \mathrm{~b}$ & $2.86 \mathrm{c}$ & $3.20 \mathrm{c}$ \\
\hline $\mathrm{T}_{2}$ & 8.95 & $29.42 \mathrm{a}$ & 39.50 & $3.35 \mathrm{~b}$ & $4.47 \mathrm{a}$ & $4.41 \mathrm{~b}$ & $4.41 \mathrm{~b}$ \\
\hline $\mathrm{T}_{3}$ & 9.04 & $30.67 \mathrm{a}$ & 40.33 & $4.25 \mathrm{a}$ & $4.62 \mathrm{a}$ & $5.14 \mathrm{a}$ & $5.19 \mathrm{a}$ \\
\hline$C V(\%)$ & 4.58 & 8.19 & 4.12 & 8.54 & 7.79 & 10.23 & 8.85 \\
\hline$S E( \pm)$ & 0.72 & 0.5259 & 0.8306 & 0.163 & 0.122 & 0.196 & 0.131 \\
\hline $\mathrm{P}>0.05$
\end{tabular}

$\mathrm{P}>0.05$

Different letters indicated significant difference within columns. 


\section{Effect of cropping pattern on yield of wheat and rice}

Different cropping patterns showed a significant impact on grain yields of wheat and their corresponding yield components except for number of spike $\mathrm{m}^{-2}$ and 1000 grain weight $(\mathrm{g})$. The highest grain yield of wheat $\left(4.04 \mathrm{tha}^{-1}\right)$ was recorded in wheat-dhaincha-T. aman cropping Table 6: Effect of tillage on the yield and yield contributing components of rice in 2010

\begin{tabular}{c|c|c|c|c|c|c|c|c}
\hline Treatments & $\begin{array}{c}\text { Effective } \\
\text { tillers hill }^{-1}\end{array}$ & $\begin{array}{c}\text { Panicle } \\
\mathrm{m}^{-2}\end{array}$ & $\begin{array}{c}\text { Grain } \\
\text { panicle }^{-1}\end{array}$ & $\begin{array}{c}1000 \\
\text { grain wt. } \\
(\mathrm{g})\end{array}$ & $\begin{array}{c}\text { Yield } \\
\left(\mathrm{t} \mathrm{ha}^{-1}\right)\end{array}$ & $\begin{array}{c}\text { Straw } \\
\text { yield } \\
\left(\mathrm{t} \mathrm{ha}^{-1}\right)\end{array}$ & $\begin{array}{c}\text { Yield } \\
\left(\mathrm{t} \mathrm{ha} \mathrm{h}^{-1}\right) \\
2008-09\end{array}$ & $\begin{array}{c}\text { Straw yield } \\
\left(\mathrm{t} \mathrm{ha}^{-1}\right) \\
2008-09\end{array}$ \\
\hline $\mathrm{T}_{1}$ & 6.87 & $180.3 \mathrm{~b}$ & $42.33 \mathrm{~b}$ & 31.00 & $2.37 \mathrm{~b}$ & $3.27 \mathrm{~b}$ & $2.45 \mathrm{c}$ & $3.27 \mathrm{~b}$ \\
\hline $\mathrm{T}_{2}$ & 8.76 & $212.9 \mathrm{a}$ & $52.44 \mathrm{a}$ & 32.67 & $4.07 \mathrm{a}$ & $4.63 \mathrm{a}$ & $3.98 \mathrm{~b}$ & $4.63 \mathrm{a}$ \\
\hline $\mathrm{T}_{3}$ & 9.87 & $236.0 \mathrm{a}$ & $57.34 \mathrm{a}$ & 33.94 & $5.62 \mathrm{a}$ & $5.08 \mathrm{a}$ & $5.36 \mathrm{a}$ & $5.18 \mathrm{a}$ \\
\hline$C V(\%)$ & 3.88 & 5.38 & 14.38 & 5.30 & 10.97 & 3.11 & 6.53 & 3.61 \\
\hline$S E( \pm)$ & 0.143 & 5.683 & 2.98 & 1.976 & 0.355 & 0.29 & 0.26 & 0.20 \\
\hline
\end{tabular}

$\mathrm{P}>0.05$

Different letters indicated significant difference within columns.

Table 7: Effect of cropping patterns on the yield and yield components of wheat in 2009-2010

\begin{tabular}{c|c|c|c|c|c|c}
\hline Cropping patterns & $\begin{array}{c}\text { No. of spike } \\
\mathrm{m}^{-2}\end{array}$ & $\begin{array}{c}\text { Spike } \\
\text { length }(\mathrm{cm})\end{array}$ & $\begin{array}{c}\text { Grain } \\
\text { spike }^{-1}\end{array}$ & $\begin{array}{c}1000 \text { grain } \\
\text { wt. }(\mathrm{g})\end{array}$ & $\begin{array}{c}\text { Yield } \\
\left(\mathrm{t} \mathrm{ha}^{-1}\right)\end{array}$ & $\begin{array}{c}\text { Straw yield } \\
\left(\mathrm{t} \mathrm{ha}^{-1}\right)\end{array}$ \\
\hline $\mathrm{C}_{1}$ & 267.9 & $8.05 \mathrm{~b}$ & $25.33 \mathrm{~b}$ & 39.33 & $2.63 \mathrm{c}$ & 4.02 \\
\hline $\mathrm{C}_{2}$ & 276.1 & $8.56 \mathrm{ab}$ & $28.56 \mathrm{a}$ & 41.11 & $3.50 \mathrm{~b}$ & 4.37 \\
\hline $\mathrm{C}_{3}$ & 285.6 & $9.61 \mathrm{a}$ & $30.89 \mathrm{a}$ & 42.33 & $4.04 \mathrm{a}$ & 4.41 \\
\hline$C V(\%)$ & 7.19 & 4.58 & 6.26 & 4.10 & 9.75 & 7.79 \\
\hline$S E( \pm)$ & 2.867 & 0.235 & 0.724 & 0.544 & 0.134 & 0.072 \\
\hline
\end{tabular}

$\mathrm{P}>0.05$

Different letters indicated significant difference within columns.

Table 8: Effect of cropping patterns on the yield and yield components of rice in 2010

\begin{tabular}{c|c|c|c|c|c|c|c|c}
\hline Treatments & $\begin{array}{c}\text { Effective } \\
\text { tillers hill }^{-1}\end{array}$ & $\begin{array}{c}\text { Panicle } \\
\mathrm{m}^{-2}\end{array}$ & $\begin{array}{c}\text { Grain } \\
\text { panicle }^{-1}\end{array}$ & $\begin{array}{c}1000 \\
\text { grain wt. }^{(\mathrm{g})}\end{array}$ & $\begin{array}{c}\text { Yield } \\
\left(\mathrm{t} \mathrm{ha}^{-1}\right)\end{array}$ & $\begin{array}{c}\text { Straw } \\
\text { yield } \\
\left(\mathrm{t} \mathrm{ha}^{-1}\right)\end{array}$ & $\begin{array}{c}\text { Yield } \\
\left(\mathrm{t} \mathrm{ha}^{-1}\right) \\
2009\end{array}$ & $\begin{array}{c}\text { Straw yield } \\
\left(\mathrm{t} \mathrm{ha}^{-1}\right) \\
2009\end{array}$ \\
\hline $\mathrm{C}_{1}$ & 8.00 & 200 & $45.45 \mathrm{~b}$ & 31.33 & $3.66 \mathrm{~b}$ & 4.07 & $3.87 \mathrm{~b}$ & 4.15 \\
\hline $\mathrm{C}_{2}$ & 8.35 & 211 & $51.11 \mathrm{a}$ & 32.56 & $4.09 \mathrm{a}$ & 4.38 & $4.14 \mathrm{ab}$ & 4.49 \\
\hline $\mathrm{C}_{3}$ & 8.96 & 218 & $52.55 \mathrm{a}$ & 33.17 & $4.32 \mathrm{a}$ & 4.63 & $4.54 \mathrm{a}$ & 4.67 \\
\hline$C V(\%)$ & 3.88 & 5.38 & 14.38 & 5.30 & 10.97 & 3.61 & 8.86 & 11.37 \\
\hline$S E( \pm)$ & 0.11 & 3.76 & 2.43 & 0.572 & 0.147 & 0.053 & 0.047 & 0.064 \\
\hline $\mathrm{P}>0.05$
\end{tabular}

$\mathrm{P}>0.05$

Different letters indicated significant difference within columns.

pattern, which was statistically superior to other cropping patterns (Table 7). In the case of rice grain yield and its yield components, significant differences among the cropping pattern treatments were recorded except for effective tillers hill ${ }^{-1}$, panicle $\mathrm{m}^{-2}$ and 1000 grain weight (Table 8). Fallow-in-between cropping pattern gave rise to the lowest grain yield of rice $(3.66 \mathrm{t}$ $\left.\mathrm{ha}^{-1}\right)$ whereas dhaincha based cropping pattern resulted in the highest rice grain yield (4.32 $\mathrm{t}$ ha $\left.{ }^{1}\right)$. Mungbean based cropping pattern produced similar significant increase in grain yield of rice 
as of dhaincha based cropping pattern. This has to do with the incorporation of biomass of dhaincha and mungbean in soils (Table 2). This result is consistent with that of Reddy et al. (1995) who stated that incorporation of biomass released nutrients to soils and enhanced crop nutrient uptake and thereby increased crop yields. However, straw yield was not significantly influenced by cropping pattern treatments as was observed similarly in the study conducted one year before. Incorporating dhaincha biomass into soil encouraged higher mineralization which resulted in additional nutrient supply than that of mungbean during the subsequent growing season for rice crop (Lal et al. 2000). As a result, a higher rice yield with dhaincha in between cropping pattern was obtained.

\section{Conclusions}

From the results of two years study, tillage practices and cropping patterns showed insignificant effect on soil physical properties but soil moisture retentive properties gave significant variation. Deep tillage with dhaincha and mungbean biomass incorporation retained moisture in the soil profile and improved other soil physical properties. Grain yield of wheat and rice was significantly increased from zero tillage to deep tillage. The highest grain yield of wheat and rice was recorded in the deep tillage with wheat-dhaincha-T. aman cropping pattern and lowest in zero tillage with fallow based cropping pattern. Deep tillage with wheat-dhaincha-T. aman cropping pattern could be recommended for the improvement of soil health and crop productivity.

\section{References}

Ahmad, W., Khan, F., and Naeem, M. 2010. Impact of cropping patterns and fertilizer treatments on the organic fertility of slightly eroded Pirsabak soil series in NWFP, Pakistan. Soil \& Environ. 29(1): $53-60$.

Ardell, D., Halvorson, A. L., Black, J. N., Krupingley, S. D., Merril, B. J., Wienhold, G., and Tonaka, K. I. 2000. Spring wheat response to tillage system and nitrogen fertilization within crop tallow system. Agron. J., 92: 151.

BARC (Bangladesh Agricultural Research Council), 2005. Fertilizer recommendation guide2005. Soils pub no, 41, Bangladesh Agril. Res. Council, Farmgate, Dhaka, 60-85

Bertolino, A. V. F. A., Fernandes, N. F., Miranda, J. P. L., Souza, A. P., Lopes, M. R. S., Palmieri, F. 2010. Effects of plough pan development on surface hydrology and on soil physical properties in Southeastern Brazilian plateau. Journal of Hydrology. 393 (12):94-104.

Black, C. A. 1965. Method of soil analysis Part -I and II. Amer. Soc. Agron. Inc. Madison, Wiscosin, USA. P. 770.

Brammer, H. 2000. Agroecological Aspects of Agricultural Research in Bangladesh, University Press Limited, Dhaka, 35-135

Cogle, A. L.,Rao, K. P. C.,Yule, D. F., George, P. J., Srinivasan, S. T., Smith, G. D. and Jangawad. L. 1997. Soil management options for Alfisol in the semi-arid tropics: annual and perennial crop production. Soil Till. Res., 44: 235-253.

Gomez, K. A. and Gomez, A. A. . 1984. Statistical Procedures for Agricultural Research 2nd Edn. IRRI, Los Banos, Languna, The Philippines, 62-74. 
Hailin, Z., Wangsheng, G. C. F. and Wenshan. Z. 2005. Prospects and present situation of conservation tillage. Journal of China Agricultural University, 2005, 10(1): 16-20.

Husunjak, S., Filipovic, D. and Kosutic, S. 2002. Influence of different tillage systems on soil properties and crop yield. Rostlinná Výroba, 48, 2002(6): 249-254.

Islam, M. S., Karim, A. S. M. S., Hossain, M. S. and Masud, M. M. 2005. Tillage and Mulch effects on some soil physical properties and yield of wheat in shallow red brown terrace soils of Bangladesh. Sarhad J. Agric. 21 (4): 655-665.

Jabro, J. D., Stevens, W. B., Iversen, W. M., and Evans, R. G. 2010. Tillage practice effects on soil physical properties, sugarbeet yield, and sugarbeet quality. Com. Soil Sci. Plant Ana., 41(5-8), 908-916.

Jabro, J. D., Sainju, U. M., Stevens, W. B., Lenssen, A, W., and Evans, R. G. 2008. Long-term tillage frequency effects on dry land soil physical and hydraulic properties. International Soil Conservation Organization Conference Proceeding. May 15-23. 2008. Budapest, Hungary, 1-4

Jenane, C., Chaplin, J. and Lueders, M. 2012. A powered flail tool for residue manipulation ln conservation tillage. For presentation at the International Seminar of the 3rd Section of the CIGR on Tillage in Arid and Semi-Arid Areas Rabat - Morocco

Karim, Z., Rahman, S. M., Ali, M. I. and Karim. A. J. M. S 1988. Soil bulk density. A manual for determination of soil physical parameters. Soils and Irrigation Division. BARC.

Katsvairo, T., Cox, W. J. and van Es., H. 2002. Tillage and rotation effects on soil physical characteristics. Agron. J., 94: 299-304.

Khan, M. S. 1996. Effect of alternate tillage practices and crop production under rice-wheat cropping sequence of Bangladesh-a thesis. Soil Physics Laboratory, Department of soil Science, Univ. of Dhaka, 12-26

Khurshid, K., Iqbal, M., Arif, M. S. and Nawaz. A. 2006. Effect of tillage and mulch on soil physical properties and growth of maize. Int. J. Agric. Biol., 8: 593-596

Husnjak, S., Filipovic, D. and Kosutic. S. 2002. Influence of different tillage systems on soil properties and crop yield. Rostlinná Výroba, 48, 2002(6): 249-254.

Lal, J. K., Mishra, B., and Sarkar., A. K. 2000. Effec of water-filled pore space on carbon dioxide and nitrous oxide production in tilled and non-tilled soils. Soil Sci. Soc. Am. J. 48: 67-71.

Mazid, M. M., Faiz, A. M. A., Khan, T. H. and Alam., M. K. 1990. Effect of soil bulk density, moisture regime on the root development of wheat. Bangladesh J. Soil Sci., 12(1): 30-35.

McFarland, M. L., Hons, F. M. and Lemon., R. G. 1991. Effects of tillage and cropping sequence on soil physical properties. Soil Till. Res., 17(1-2): 77-86.

Oquist., K. A., Sttrock, J. S. and Mulla, D. J. 2006. Influence of alternative and conventional management practices on soil physical and hydraulic properties. Vadose Zone Journal 5: 356-364.

Rahman, M. M. and Ranamukhaarachchi, S. L. 2003. Fertility status and possible environmental consequences of Tista Floodplain soils in Bangladesh. Tham. Int. J. Sci. Tec., 8(3):11-19.

Rahman, M. N., Rahman, M. M., Islam, M. B., Begum, R. A., and Mondol, A. T. M. A. I. 2007. Effect of tillage practices on soil properties and moisture conservation under Maize -GMT. Aman cropping sequence. Annual Research Report-2007. Soil Science Division. Bangladesh Agricultural Research Institute, Gazipur, 12-18. 
Rahman, S. M. and Islam, A. 1998. Water transmission properties of two Bangladesh soils as affected by tillage practices. Soil water flux and hydraulic conductivity. AMA. Res., 10(3): 307-312.

Ranamukhaarachchi, S. L., Rahman, M. M., and Begum, S. N. 2005. Soil fertility and land productivity under different cropping systems in highlands and medium highlands of Chandina sub district, Bangladesh. Asia Pacific J. Rural Dev., XV(1): 63-76.

Ranjan, B., Singh, R. D., Chandra, S., Kundu, S., and Gupta, H. S. 2006. Effect of tillage and irrigation on yield and soil properties under rice, wheat system on a sandy clay loam soil of Uttaranchal, Indian. J. Agric. Sci., 76(7): 405-409.

Reddy, S. R. and Hukkeri, S. B. 1995. Effect of tillage practices on irrigation requirement, weed control and yield of low land rice. Soil Till. Res., 3: 147-158.

Rijpma, J. and Jahiruddin, M. 2004. National strategy and plan for use of soil nutrient balance in Bangladesh. A consultancy report, SFFP, Khamarbari, Dhaka, 7-26

Sharama P.K., Pantuwan, G., Ingram, K. T. and de Datta, S. K. 1994. Rainfed lowland rice roots: soil and hydrological effects. In. Rice roots: nutrient and water use. Ed. G.J.D. Kirk. IRRI, P.O.. Box933, Manilla, Philippines, 67-77

Simmons, F.W. and Nafziger, E. D. 2012. Soil Management and Tillage. Illinois Agronomy Handbook. http://extension.cropsci.illinois.edu/handbook/pdfs/chapter10.pdf

Singh, P. K. C., Aipe, R., Prasad, S. N., Sharma, S. and Singh, P. 1998. Relative effect of zero and conventional tillage on growth and yield of wheat and soil fertility under rice-wheat cropping system. Indian J. Agron. 443(2): 204-207.

SRDI. 2005. Bhumi and Mrittika Sampad Bhavohar Nirdeshika, Gazipur Sadar Upazila, Gazipur Zilla. Soil Resource Development Institute. Ministry of Agriculture, Government of the Peoples Republic of Bangladesh, 5-15

Wickramasinghe, W. M .A .D .B. 2011. Influence of plough layer depth on growth and yield of rice. Rice Research and Development Institute, Batalagoda, Ibbagamuwa. Sri Lanka, 110 